\title{
New Connotation of Financial Management under the Background of Internet +
}

\author{
Sheng Shujun \\ School of Management, Tianhua College \\ Shanghai Normal University \\ Shanghai, 201815
}

\begin{abstract}
In the Internet+ era, human society is experiencing an unprecedented transformation as enterprise are undergoing cross-border integration, structural reorganization, strategic innovation, management improvement to create a new future. The change of business model and marketing model requires the transformation of management mode. Changes take place in financial management with the transformation of financial management model, which can be seen in the need for financial data sharing platform, the need to enhance management accounting research and application, the need for a specific financial strategic system, and the need to strengthen the cultivation of compound talents financial management.
\end{abstract}

Keywords-Internet +; financial management; management accounting

In recent years, with the rapid development of technologies such as the Internet and cloud computing, it is questions worthy of consideration for financial managers that how can traditional financial management adjust to face new technological changes and challenges [1]. The advent of the era of Internet + requires us to change our minds more quickly, keep pace with the times, and also puts forward higher requirements for business and financial managers.

\section{CHARACTERISTICS OF THE INTERNET + ERA}

\section{A. Abundant real time information}

The biggest feature of the Internet era is the information overload. And the internet era excels the traditional media era in both information quantity and types. Informatization has accelerated the penetration of the social economy and the daily life of the public, and has brought large amounts of data with rich content, complex structure and various forms. Cloud technology has increased the data storage capacity, which has increased the continuity of data acquisition. More and more structured, unstructured and semi-structured data sources are continuously shared from various network terminals. Through the Internet, people are enjoying rich data never seen before [1].

\section{B. Diversified information platforms [2]}

The Internet age has brought platforms for people to compete. From a personal point of view, QQ, WeChat, Weibo, Taobao and other diverse platforms have changed people's lives, making it easier for people to communicate with each other and improving people's work efficiency. From an enterprise perspective, Tencent, Baidu, Ali, JD, 360, etc., are using these platforms in the network era to stand out from the competition and make great achievements.

\section{Openness of the environment}

Openness is the most prominent feature of the network environment. The network narrows the distance between people, people and nature, and people and the world. In an open environment, everyone can produce, receive and spread information. Particularly, with the development of We Media, everyone can express their views independently, and everyone is equal, while personalization and differentiation become the commanding heights pursued by individuals and enterprises.

\section{The AbILITy ReQuired IN THE INTERNET + ERA}

\section{A. With the awareness of resource sharing and} cross-boundary integration

The rapid development of Internet and mobile internet, together with the shock of big data, facilitates the sharing of resources across the globe without geographical and time constraints by subverting the original rules of the game and the ways of control [3]. Therefore, closed and conservative becomes the barrier of thinking that must be broken first in the era of Internet + economy. Moreover, cross-border integration must become a new way of thinking and behavior. Focus on connectivity and build an ecosystem that connects everything. That is the essence of "Internet +" which capitalizes on network to apply the latest information technology to multiple fields and industries to bring about fundamental changes and developments in the entire industry. Cross-border integration has become an inevitable trend.

\section{B. With the thought of management going first and the strategy being supreme}

With the ongoing innovations in the business model, the logic of management has changed a lot. As the power centers of producers and consumers have undergone great shift, and connections and relationships have increasingly become the important elements pursued by enterprises. In the Internet+ era, the asymmetry of information reduces, decreasing the transaction costs of the entire society and improving the operational efficiency of the whole society. However, competition has also reached a fever pitch. As all enterprises are expanding their thinking and finding opportunities for survival and development, chaos and uncertainty become temporary normal. Enterprises have no choice but to change management methods, and use advanced management thinking 
and approaches to improve the effectiveness and performance of corporate strategy [4].

\section{With the ability of innovation and individualized development}

Innovation is the vitality of an enterprise, that is, the innovation drives the development of an enterprise. The innovation in the Internet+ era is even more necessary, and has even become the norm of enterprises [5]. Only by continuously innovating and establishing the distinctive characteristics, can enterprises rise above from the crowd in the fiercely competitive market under the Internet + . Therefore, one should have innovative thinking, be able to carry out differentiated management and enhance the individualized service of the enterprise. Carrying out operation and management activities based on the characteristics of the times is the inevitable trend of enterprise reform and development under the Internet + . At the same time, enterprise itself must possess innovation capability and be able to provide customized service.

\section{The New Connotation Requirements of}

FinANCIAL MANAGEMENT IN THE ERA OF INTERNET +

\section{A. Build financial data sharing service platform}

The traditional financial work is mainly financial accounting. The financial staffs mainly cope with repetitive basic works while neglecting the core financial management work which consists of, for example, the in-depth analysis of financial data, the operation of funds, tax planning, etc. They generally do not participate or have no energy to devote themselves into these works. In contrast, in the era of Internet+, enterprises can obtain production information, sales information, warehousing information, financial information, etc. during the production and operation process in real time. In this respect, drawing conclusions by data analysis to support management decisions has become common. In the traditional environment, the decentralized functional management departments, such as personnel department, finance department, and operation department, must work in a shared service mode in the context of the Internet + . In this way, the enterprise can adapt to the Internet and maximize the use and integration of information [6].

However, if enterprises want to achieve financial sharing, they have to integrate resources and solve bottlenecks. The specific resources needed for integration are as follows:

1) Establish a shared service platform for repetitive basic financial work

Financial accounting addresses the collection and processing of accounting information, which is the basic work of corporate finance. The shared service platform is developed on the basis of the original financial system. It takes in and improves the receivables and payables, fixed assets, salary accounting, general ledger statements, and expense reimbursement, which addresses the decentralized operation and low efficiency in the traditional financial model. Additionally, it capitalizes on the new software to reorganize financial processes, and better manages financial work with new models and processes to ensure efficient financial operations.

\section{2) Create a shared service platform}

The development and applications of financial shared service $^{[3]}$ mean the great changes in financial operation. To realize service sharing, enterprises must establish a shared service platform for the core staff to complete the work. What's more, the platform can address the transfer, review and approval of the original documents in other areas. For example, the original documents can be scanned and uploaded to the platform through the image scanning system, barcode and QR code. On the shared service platform, you can see all types of business documents ${ }^{[6]}$ transferred by each branch, including collection order, payment order, expense account, funds collection and payment, etc., so that data sharing and utilization can be maximized.

\section{3) Business and financial integration}

Finance is a management that reflects and monitors all business operations. And business is the source of a company's profit. Therefore, planning the financial management activities of enterprises from the perspective of business is an inevitable trend for the future financial management of enterprises[5]. The construction of the financial sharing platform must be consistent and compatible with the business. Otherwise the documents of the business activities cannot be transferred to the financial system of the shared service center. Given this, financial sharing system performs practically no function as the shared services cannot be carried out.

\section{B. Increase management accounting researches and applications}

Financial accounting and management accounting are the two branches of corporate finance. The former mainly includes accounting, preparing financial statements, and generating external financial reports, while the latter mainly involves analysis of variable cost method, comprehensive budget and responsibility accounting and volume-cost-profit analysis, which aims at internal management, and looks for ideas and responsibilities for administrators to improve their management capability.

In the Internet+ era, the basic accounting work can be completed through the above-mentioned financial service sharing platform. Then the priority of the corporate finance department will shift from accounting to management accounting, that is, from accounting-based finance to managed finance. The key to this transformation is to combine the company's finances and strategies to enable finances participate in the overall budget management of the strategies, which can greatly promote management accounting, and allow the management accounting to better serve the enterprise strategy [7].

Continuously promote management accounting, better forecast business operations, conduct business plan budgeting, issue financial analysis reports, and provide effective data support for business department assessments. Use big data technology to gather financial and non-financial information into the accounting system, and make reports on all aspects of management to provide reference for various decisions of enterprises. We should learn to use advanced management accounting tools such as strategic maps and balanced scorecards in management accounting, and focus financial 
work on internal management. In addition, we should focus on the internal work of the company such as process control and performance analysis, so as to raise the financial work to the strategic level and realize the delicacy management of the enterprise.

\section{Have a clear financial strategy system}

The financial strategy that focuses on the bright future of the company is an in-depth application of corporate financial management, and it will be made with consideration of the overall chain of corporate financial activities [4]. In the era of Internet+, market information is transparent, and the space for enterprises to play tricks on prices gets smaller. Given this, it is necessary to further strengthen the internal management of enterprises, strengthen the role of management accounting, and obtain profitability from inner-enterprise. In the application of management accounting, we should take corporate strategy as the guide, study corporate capital arrangements to realize the balanced and effective capital flow, so as to increase financial competitive advantage. Based on the analysis of the impact of internal and external factors on capital flows, we can make an overall, long-term and creative plan on capital flow and ensure the effective implementation. All these are important to an enterprise. This also means that the company should have a clear financial strategy system that can be planned from the entire supply chain to achieve optimal allocation of resources.

\section{Strengthen the training of financial management compound talents}

Talent is the key point of future competition. Therefore, the cultivation of compound financial management talents is an important part of the financial management work in the Internet+ era [8].

In terms of personnel training, financial management personnel must have overall strategic thinking, insight on opportunities and moderate risk management and internal control capabilities, and be sensitive to the business environment and related data. This requires colleges and universities to increase the relevant curriculum content for cultivating the talent for financial management from the source of talent cultivation [8].

In terms of talent development, it requires that talents should be equipped with comprehensive financial budgeting and financial analysis capabilities and can expand resources. The talents should have the ability to calculate profitability, debt paying ability and be capable at value creation and appreciation. Moreover, they should keep learning, making innovation and making professional progress. Only in this way, can they better adapt to the complex requirements of talents in the Internet + environment. Enterprises are also required to increase financial investment in cultivating talents.

\section{PROSPECT AND CONCLUSION}

The change of the times will inevitably generate the transformation of the operation strategy of the enterprise, and the change of operation will inevitably lead to the change of management. The financial work in the Internet + era should shift its focus from simple, trivial, and low-level financial accounting to complex, critical, and advanced management accounting. Financial management should take the financial data sharing service platform as data processing tool. And it is necessary to enhance the management accounting research and application. Enterprises need to possess a clear financial strategy system and strengthen the training of financial management compound talents.

\section{REFERENCES}

[1] Yuan Zhenxing, Zhang Qingna. The Challenge of Big Data to Accounting and Its Countermeasures [J]. Friends of Accounting, 2014.11.(In Chinese)

[2] Qin Changcheng. Internet+: Cracking the Financial Predicament of Small and Micro Enterprises [J]. Corporate Finance.2016.01(In Chinese)

[3] Wang Yanhong. On Financial Management in Internet + Times [J]. China New Telecommunications, 2016. 1(In Chinese)

[4] Sheng Xiaohe. On the Impact of Big Data on Enterprise Financial Management [J]. Chinese \& Foreign Entrepreneurs.2016.03(In Chinese)

[5] Liang Tongying, Chen Guangbin, Chen Guangbing. On the Financial Management Mode Innovation of SMEs under the Network Environment [J]. Accounting Research, 2003.05(In Chinese)

[6] Shao Jianyuan. On Financial Management under the Internet Environment [J]. Accounting Learning.2016.01(In Chinese)

[7] Qin Changcheng. Internet+: Cracking the Financial Predicament of Small and Micro Enterprises [J]. Corporate Finance.2016.01(In Chinese)

[8] Gan Yuanyong. On the Dilemma of Financial Management Profession [J]. China Collective Economy.2016.03(In Chinese) 